DOI https://doi.org/10.30525/978-9934-588-63-1.24

\title{
CRIMINAL LIABILITY FOR COLLABORATIONISM: IS THERE A NEED TO ESTABLISH IT IN UKRAINE?
}

\section{Politova A. S., Akimov M. O.}

\section{INTRODUCTION}

In modern conditions shaping the implementation of state policy in the area of national security still is one of strategically vital aspects that require extra attention - with regard to the restoration of territorial integrity of Ukraine, deoccupation and integration of separate districts in Luhansk and Donetsk regions, where state bodies do not exercise their powers. This process is truly complicated and multifaceted; it generates the need to solve the number of political, economic, social, cultural, ideological, environmental and other problems. Establishment of peace in Eastern Ukraine will be also tightly connected with the recovery of state power bodies functioning along with local self-governance, law and order maintenance. The latter, in particular, puts another problem in focus - legal responsibility of subjects who, since 2014, have collaborated with self-proclaimed "LPR" and "DPR" ("Luhansk People's Republic" and "Donetsk People's Republic") in different ways.

The concept of collaborationism have been studied intensively by many Ukrainian legal scholars including O. Holovkin, O. Illarionov, M. Rubashchenko, Y. Pysmensky, I. Skazko etc. along with historians, psychologists and political analysts.

The aim of this paper is to study the essence of collaborationism concept and analyze the drafts establishing its criminalization.

\section{Disputable matters related to definition of "collaborationism"}

The term "collaborationism" is quite often met in historical and political literature and used to define the voluntary cooperation (collaboration) of separate groups or social domains of the occupied territories with occupational authorities.

Analysis of available publications proves that there is no single approach presented to interpret this definition. This phenomenon got the most significant attention in the context of World War II researches, and certain its aspects have become a research target in connection with the events in Eastern Ukraine where the Joint Forces Operation is sustained (in 2014-2018 - Anti-Terrorist Operation). Research in the above-mentioned area was stimulated by 
presentation of certain proposals from the subjects of legislative initiative Ukrainian MPs - in order to establish the criminal liability for collaborationism.

K. Pyvovarska notes that in the broadest sense of the term "collaborationism" (originates from French "collaboration" - "cooperation") defines collaboration with invaders within the territory they have occupied but usually this word is massively used to mark the cooperation with Nazi occupiers during WWII. At first this phenomenon was considered to be a result of implementing the cooperation policy of Vichy France (established after occupation of France within the untouched its part (one third of the state territory) and headed by Marshal Henri-Philippe Pétain), then accompanied by the Quisling's activity in Norway to be later used as a standardized concept for all occupied nations ${ }^{1}$. In researcher's opinion, collaboration may be voluntary (for example, joining the volunteer military units) or forced (e.g. nomination as the village head), but often these are easily confused ${ }^{2}$.

For the first time collaborationism was mentioned as illegal act with relevant liability in France as well - under the laws passed by the Consultative Assembly on August 24 and September 26, 1944, having established responsibility for collaboration, a threat to "national unity, the rights and equality of all French citizens" 3.920 persons were executed, 1.500 sentenced to imprisonment at hard labor, and 39.000 were convicted to other imprisonment terms. In addition, approximately 9.000 people were executed without trial, and almost 20.000 women were publicly shamed for their ties to the Germans. Marshal Pétain was also sentenced to death, but Charles de Gaulle commuted the death sentence to life imprisonment (in 1951 Pétain died in prison). In 1953 an amnesty was announced for former collaborators, but the collaborationism was kept outside the public discourse frame for a long time. Charles de Gaulle restored the French Republic, and the ideology of the "national revolution" proclaimed by Pétain, although not completely abandoned, was marginalized ${ }^{3}$.

During the World War II part of the population of European and Asian countries cooperated with the Axis military and civilian authorities. As for the Soviet Union, the manifestations of collaborationism among its inhabitants are particularly significant in this aspect. In total, 5.74 million of the USSR citizens were captured by Germans (in 1941 - numerically almost the entire regular Red Army). Till the end of that year 318.000 servicemen were released from captivity by place of residence on their own recognizance. In 1942-1944,

\footnotetext{
${ }^{1}$ Пивоварська К. Колабораціонізм у Другій світовій війні. 1941 рік на Полтавщині: людський вимір трагедії та героїзму : збірник статей за матеріалами міжнародної наукової конференції (28 вересня 2011 року). Полтава : ПОІППО, 2011. С. 101.

2 Ibid.

3 Литвиненко О.М. Досвід національного примирення: різні шляхи до однієї мети. Стратегічні пріоритети. 2019. № 1. С. 46.
} 
505000 people were released from captivity, but transferred to German military service (including up to 280000 Russians, $60000-70000$ representatives of the ethnic groups from Caucasus, Volga region and Central Asia and only 60000 70000 Ukrainians) $)^{4}$.

Since the very first days of war a large number of residents of the occupied USSR territories, wearing German uniforms, were deployed to all positions taken by German armed forces. These were named "Hiwi" (from German "Hilfswillige" - voluntary assistant). Thus, the staff of the infantry division as of October 1943 provided 2.005 volunteers for 10.708 German servicemen. In addition to the ground forces (Wehrmacht), USSR volunteers also served in the Air Force (Luftwaffe) and Navy (Kriegsmarine) units. According to some estimates, in spring of 1943 their number exceeded 1 million people. In total, during the war 180 separate units and formations composed of USSR nationalities were established be Germans ${ }^{5}$.

The fact of collaborationism in the Soviet Union cannot be denied also because it is confirmed with decisions taken by the highest Soviet power bodies. On December 27, 1941, Stalin signed a resolution of the State Defense Committee No. 1074 - it stated that, according to decision of the USSR NKVD Special Council, permission was given to send families of persons who voluntarily withdrew with Nazi troops and served in the administrative and punitive bodies of German authorities troops to remote northern regions ${ }^{6}$. Nevertheless, despite numerous directives from the USSR NKVD aimed to prosecute the family members of persons accused of treason, this issue did not receive proper attention. On May 30, 1942, the State Defense Committee in its Directive No. 215/51 proposed to launch the repression of traitors' family members immediately. They were subject to arrest and exile in separate USSR areas:

- adult members of the families of servicemen convicted by USSR NKVD Special Council or by judicial authorities for escape to another state (according to Part 2 of Article 58-1 of the Criminal Code of the Russian SFSR and the relevant articles of the Criminal Code of other Soviet republics);

- commanders and political workers who tore off their insignia and deserted or surrendered to enemy during the battle (Order of the Army Supreme High Command General Headquarters Stake of the Red No. 270 of August 16, 1941).

Another resolution of the State Defense Committee No. 1926 of June 24, 1942 "On members of the traitors" families" recommended the following to and

\footnotetext{
${ }^{4}$ Колабораціонізм у роки Другої світової війни. URL: http://www.adm-pl.gov.ua/story/kolaboracionizmu-roki-drugoyi-svitovoyi-viyni (Last accessed: 29.05.2020).

${ }^{5}$ Ibid.

${ }^{6}$ Коровин В.В. Правовая ответственность коллаборационистов в период Великой Отечественной войны. URL: https://elibrary.ru/download/elibrary_24371447_64111459.pdf (Last accessed: 29.05.2020).
} 
the Prosecutor of the USSR in addition to the above-mentioned directive: adult members of the traitors' families (servicemen and civilians) convicted by judicial authorities or by USSR NKVD Special Council were subject to arrest and exile in remote areas of the USSR for up to 5 years if sentenced to capital punishment under Articles 58-1 "a" and 58-1 "b" of the Criminal Code of the Russian SFSR and the relevant articles of the Criminal Code of other Soviet republics for: espionage in favor of Germany and other countries fighting against the USSR; choosing the enemy's side; treason or aid provided to German occupiers; service in the punitive or administrative bodies of the German occupiers within the captured territory; for attempted treason and treacherous intentions; for voluntary retreat with the occupying forces during the liberation of the territory captured by the enemy. Repressions against family members of the above-mentioned persons were massively executed by NKVD on the basis of judgments by judicial bodies or decisions of USSR NKVD Special Council?. Taking this into account, we may state that both collaborationism and liability for the cooperation with occupants existed in Soviet Union.

V. Chachava indicates that in 1941, when Germany initiated the war against USSR, one of key tasks Nazi urged to perform was to destroy the multinational Soviet state and bring the representatives of ethnic minorities into the fold (italics - Anna Politova and Mykhailo Akimov). The Germans believed that they would be able to incite hostility, raise the non-Russian peoples to fight against the Bolshevik empire, and thus facilitate their victory. They wanted to establish a certain structure on the ruins of the USSR comprising territorial and ethnic formations and implementing the German policy with aim to spread its influence in the Middle and Far East ${ }^{8}$. And to certain extent they managed to achieve it.

Exploring the problem of collaborationism, V. Shaikan notes that it is a complex, ambiguous socio-psychological and ethical phenomenon that emerges as a result of interaction between the subjects of communication process (population of the occupied states and occupiers), i.e. cooperation with the enemy under occupation regime. During the Second World War it was presented in various manifestations - manifested itself in a wide range - from individual level to military, economic, cultural, administrative, individual and political forms ${ }^{9}$.

\footnotetext{
${ }^{7}$ Коровин В.В. Правовая ответственность коллаборационистов в период Великой Отечественной войны. URL: https://elibrary.ru/download/elibrary_24371447_64111459.pdf (Last accessed: 29.05.2020).

${ }^{8}$ Чачава В. Кавказький вектор колабораціоністської політики Третього рейху (1991-1945). Icmopuкополітичні проблеми сучасного світу : зб. наук. пр. 2015. Т. 29-30. С. 343.

${ }^{9}$ Шайкан В. Колабораціонізм в Україні у роки Другої світової війни. URL: http://www.kby.kiev.ua/ komitet/conference/Shajkan2.pdf (Last accessed: 29.05.2020).
} 
Applicable Ukrainian legislation does not contain concept of "collaborationism" in the sense of citizens' voluntary or forced cooperation with the occupier's administration. The National Security Strategy of Ukraine (approved by the Decree of the President of Ukraine dd. 26.05.2015 No. 287/2015) does not include collaboration as a threat to national security; key areas of the state policy on political and legal framework of collaborationism countering are also not defined.

According to V. Dukhnevych, Russian authorities are trying to convince the residents of the annexed Crimea and ORDLO (uncontrolled areas of the Donetsk and Luhansk regions) that those who remained in the occupied territories must be considered as "traitors" by Ukraine. Lawyers are still to provide their professional opinion regarding the actions of our compatriots staying in the occupied territories, but we can already predict that all civil officials of the selfproclaimed "LPR" and "DPR" will be pardoned ${ }^{10}$.

Ukrainian legal encyclopedia contains the definition of "collaborationists" subjects who cooperated the occupier's authorities within the territory of states temporarily captured by the Nazi during WWII ${ }^{11}$. Encyclopedia of Ukrainian History defines "collaborationism" as voluntary cooperation (in opposition to forced cooperation) of separate groups and social domains of the occupied territories with the invaders ${ }^{12}$.

Naturally, we should distinguish between collaborationism as a comprehensive phenomenon and the corresponding activity as a purely subjective (practical) side of the mentioned phenomenon. Modern researchers distinguish between collaborationism, which involves a political agreement with the occupier (cooperation with the occupying power in civilian areas), and collaborationism as a fighting in favor of the occupying forces. In addition, within different activity types collaboration may exist in various forms domestic, administrative, economic, military, political and military-political. The latter two forms were the most common (and punishable) in Europe during World War II, resulting in establishment of nominally independent governments or administrative institutions, pro-Nazi movements and parties along with formation of foreign legions.

Due to the recent events taking place in Eastern Ukraine, discussions related to the criminalization of such socio-political phenomenon present in the temporarily occupied territories of Ukraine as collaborationism have intensified.

\footnotetext{
${ }^{10}$ Духневич В.М. Психологічні наслідки воєнного конфлікту на Сході: теоретичний аналіз явищ політико-правової сфери. Наукові студї із соціальної та політичної психологї. 2018. Вип. 41. С. 43.

${ }^{11}$ Юридична енциклопедія: в 6 т. / редкол.: Ю.С. Шемшученко (голова редкол.) та ін. Київ : Українська енциклопедія, 2001. Т. 3: К-М. 2001. С. 145.

12 Дерейко I.І. Колабораціонізм. Енциклопедія історії України: в 10 т. / редкол.: В.А. Смолій (голова) та ін.; Інститут історії України НАН. Київ : Наукова думка, 2007. Т. 4. С. 440.
} 
M. Rubashchenko claims that collaborative activity of Ukrainian citizens is already criminalized by the applicable Criminal Code within fixed forms of treason. Its expansion will lead to certain danger of blurring the criminal liability boundaries and will threaten the rights of residents of the occupied territories. Instead, the legislator must update the criminal legislation in terms of liability for providing assistance (facilitation) to the occupying power carrying out subversive activities against Ukraine, involving foreigners and stateless persons ${ }^{13}$. Y. Pysmensky stresses that the idea of criminal liability establishment for collaborationism is becoming more and more acute as parts of Ukrainian territory are still beyond the control of our government ${ }^{14}$. Both researchers think that criminal liability for all forms of collaborationism is not needed as certain provisions of the Criminal Code of Ukraine establishing liability for crimes against national security, public safety and order are already sufficient.

In order to define the concept of collaborationism along with its features and feasibility of criminal liability establishment for such actions we consider it appropriate to analyze the provisions of certain drafts registered by Ukrainian MPs.

\section{Legislative initiatives on collaborationism criminalization}

Collaborationism in its various forms and manifestations is inherent in any armed conflict followed by occupation. But modern collaborationism is different as it evolves in Ukraine under conditions of a hybrid war. There are number of issues related to the complexity of legal assessment when it comes to participation in rallies or illegal referendums and elections in Crimea and Donbas in support of the occupying power, participation in the establishment and functioning of occupying authorities, public appeals to support or cooperate with Russian occupation authorities, etc.

It is known that criminal liability arises after commission by a person of a socially dangerous act with certain characteristics (Article 2 of the Criminal Code of Ukraine). However, the trends of recent years indicate that the legislator is increasingly trying to counteract not certain, clearly defined acts, but specific phenomena with the help of criminal regulations. As a result, the concepts of terrorism, corruption, and domestic violence are presented in the criminal law; it

\footnotetext{
${ }^{13}$ Рубащенко М.А. Кримінальна відповідальність за колабораціонізм за чинним КК України. Соціальна функція кримінального права: проблеми наукового забезпечення, законотворення та правозастосування : матеріали міжнар. наук.-практ. конф. (м. Харків, 12-13 жовт. 2016 р.). Харків, 2016. C. 331.

${ }^{14}$ Письменський Є.О. Кримінально-правова політика України із забезпечення охорони національної безпеки в умовах гібридної війни. II Львівський форум кримінальної юстиції «Правова реформа у сфері кримінальної юстиції: ключові параметри та прогноз подальшого розвитку» : збірка тез міжнар. наук.практ. конф. (Львів, 23-24 верес. 2016 р.). Київ : ВАITЕ, 2016. С. 160.
} 
is proposed to criminalize extremism, separatism, collaborationism, etc., i.e. complex phenomena that are not subject to criminalization by definition.

Collaborationism - in various forms and manifestations - is inherent to any armed conflict followed by occupation. However, modern collaborationism in Ukraine exists in a hybrid war context. There are certain questions arising with regard to legal assessment of involvement in rallies, illegal referendums, elections organization in Crimea and Donbas to support the occupying power, participation in establishment and operation of occupying authorities, public appeals to support or cooperate with the occupying authorities, etc.

Cases of collaborationism have already been recorded during armed conflicts within the territory of the former USSR (in Moldova, Georgia, Azerbaijan, etc.). But no country in the world has an applicable law on liability of collaborators. Thus, we can only rely on the 1940-1950s legal practice ${ }^{15}$.

Given that after the restoration of state sovereignty in the Autonomous Republic of Crimea and certain districts of Donetsk and Luhansk regions, where public authorities are not capable of exercising their powers, the issue of liability established for persons who cooperated with the occupiers or performed functions in unrecognized public authorities will appear on the agenda, and relevant solution is the task primarily for the legislator with involvement of law enforcement agencies.

The analysis of bills registered in the Verkhovna Rada of Ukraine shows that MPs have already attempted to criminalize the collaboration four times (italics by Anna Politova and Mykhailo Akimov). At the same time, in March and December 2017, three bills were registered, and the last (fourth) - in December 2019; these initiatives have provoked active discussions among forensic scientists and representatives of civil organizations, evidently demonstrating the need for detailed analysis.

The first draft law on the prohibition of collaboration, submitted by the Verkhovna Rada MP I. Lapin (No. 6170, registered on 09.03.2017), proposes to define collaborationism as cooperation of Ukrainian citizen with the Russian occupation authorities and illegal armed formations created or supported by the Russian Federation in the Autonomous Republic of Crimea and the city of Sevastopol, as well as in temporarily uncontrolled territories of Donetsk and Luhansk regions. Legislator outlines the following forms of collaborationism:

- organization and participation in rallies to support the Russian occupation authorities, as well as in referendums and elections held by the Russian occupation authorities;

\footnotetext{
${ }^{15}$ Колабораціонізм і амністія: необхідність суспільного діалогу. URL: https://espreso.tv/article/ 2018/06/06/ kolaboracionizm_i_amnistiya_neobkhidnist_suspilnogo_dialogu (Last accessed: 29.05.2020).
} 
- public appeals aimed at supporting or cooperating with the Russian occupation authorities;

- conducting business activities with the Russian occupation authorities and business entities located in the territory of the Autonomous Republic of Crimea, the city of Sevastopol and in certain districts of Donetsk and Luhansk regions, regardless of its place of registration;

- obtaining or using passports or other documents issued by illegal organizations;

- joining the Russian occupation authorities;

- any other forms of cooperation with the Russian occupation authorities and illegal armed groups created or supported by the Russian Federation.

According to the bill collaborationism does not stipulate:

- expression of opinions by the representatives of Ukraine at the official negotiations regarding the settlement of armed confrontation in Eastern Ukraine, provided that such an opinion is not aimed at harming the sovereignty and territorial integrity of Ukraine;

- actions which contain features of collaboration in accordance with this Law, but committed by persons who performed the tasks of the Ministry of Defense of Ukraine, the Security Service of Ukraine, the Foreign Intelligence Service of Ukraine, the Ministry of Interior of Ukraine or the State Border Guard Service of Ukraine.

The Criminal Code of Ukraine was proposed to be complemented by Article 111-1 "Collaborationism", which would establish liability for the following actions:

"1. Cooperation of Ukrainian citizen with the Russian occupation authorities and illegal armed groups created or supported by the Russian Federation in the Autonomous Republic of Crimea and the city of Sevastopol, as well as in temporarily uncontrolled districts of Donetsk and Luhansk regions, except as provided by Article 3 "On the prohibition of collaborationism", -

shall be punished by imprisonment for a term from twelve to fifteen years with or without confiscation of property.

2. Citizens of Ukraine who have been forced to cooperate with the Russian occupation authorities and illegal armed groups created or supported by the Russian Federation under the threat of physical coercion or torture shall not be held liable for collaboration".

Ambiguity, vagueness of the "collaborationism" definition, the differentiation of its forms, content of the actions which already fall under criminal liability according to the Criminal Code of Ukraine provides, not only obstructed the determination of illegal socially dangerous acts are illegal, but could potentially lead to a contradiction in certain provisions. As for the incentive norm, it is 
generally accepted that in order to be exempt from criminal liability, a set of statutory requirements must be presented (to be met by a person having committed a socially dangerous act; based on the content of the proposed regulations, it is unclear what conditions this person must exactly meet).

The legislator's statement - "when our compatriots defend the sovereignty and territorial integrity of Eastern Ukraine at the cost of their own lives and health, some citizens successfully cooperate and continue their business relations with the Russian occupation authorities, increasing their profit" does not seem justified ${ }^{16}$.

Verkhovna Rada MPs S. Vysotskyi, A. Levus, I. Lapin, M. Bondar, M. Velychkovych, D. Tymchuk, T. Kremin, I. Brychenko, O. Medunytsia were the initiators of the second bill No. 7425 ("On the protection of Ukrainian statehood from the manifestations of collaborationism" registered on 20.12.2017). It is interesting that, according to the procedure, an alternative bill must be submitted within 15 days after the initial one. But, as we can see, the first draft was registered on March 9, the second - on December 20. And although, according to their authors, these documents seem to regulate different areas and are considered by different committees, even the titles of the drafts make it clear that regulated issues are identical ${ }^{17}$.

The preamble states that the draft establishes legal and organizational framework for the inspection, as well as measures against citizens of Ukraine who have assisted or are assisting the enemy in aggressive actions performance, the unfolding of armed conflict against Ukraine, including support for selfproclaimed entities or those established by the enemy bodies, performing the functions inherent to public authorities or local governments within the temporarily uncontrolled territories of Ukraine.

Article 2 of the draft law defines the main terms, including "collaborator", "collaborationism", "cooperation with the enemy" and "assistance in aggressive actions performance, the unfolding of armed conflict against Ukraine". In particular, the collaborator is understood as a person who cooperated or is cooperating with the enemy in aggressive actions, performance, the unfolding of armed conflict against Ukraine; contributed or is contributing to the implementation of such aggression or escalation of the conflict; provided or provides assistance to the enemy in the preparation and performance of such aggressive actions and escalation of armed conflict. In its turn, collaborationism is defined as cooperation with the enemy, assistance in aggressive actions performance, unfolding of armed conflict against Ukraine, providing assistance

\footnotetext{
16 Проєкт Закону про заборону колабораціонізму (реєстр. № 6170 від 09.03.2017). URL: http://w1.c1.rada. gov.ua/pls/zweb2/webproc4_1?pf3511=61312 (Last accessed: 29.05.2020).

17 Законопроєкти проти «колаборантів»: відповідальність - чи кара «наосліп»? URL: https://jfp.org.ua/ blog/blog/ blog_articles/23 (Last accessed: 29.05.2020).
} 
to the enemy in the preparation and performance of such aggressive actions and escalation of armed conflict. The authors of the bill also clarified cooperation with the enemy as any kind of participation, commission of joint actions with the enemy aimed at compromising the sovereignty, territorial integrity and inviolability, defense capacity, state, economic or information security of Ukraine, assistance in aggressive actions performance against Ukraine, unfolding of an armed conflict; any activities aimed to facilitate, assist, support the enemy in performance of actions aimed at compromising the sovereignty, territorial integrity and inviolability, defense capacity, state, economic or information security of Ukraine. Assistance to the enemy during the preparation and conduct of aggressive actions, in the development of armed conflict means the transfer to the enemy of tangible and intangible resources for actions aimed at damaging the sovereignty, territorial integrity and inviolability, defense, state, economic or information security of Ukraine ${ }^{18}$.

Identified forms of collaborationism:

1) ensuring the participation of regular troops, advisers, instructors and mercenaries in hostilities within the territory of Ukraine;

2) conducting reconnaissance, subversive and sabotage activities;

3) actions aimed at inciting interethnic, interconfessional, social disturbance and hatred, separatism and terrorism;

4) establishment and comprehensive support of bodies, self-proclaimed or initiated by the enemy, which performed or are performing the functions of state authorities or local self-government bodies within the temporarily occupied territory of Ukraine;

5) occupation and annexation of Ukrainian territories;

6) building up military groups near the Ukrainian borders and within the temporarily occupied territories, in particular, deployment of tactical nuclear weapons;

7) the formation of extremist criminal armed groups, whose activities are aimed at destabilizing the internal socio-political situation in Ukraine, disruption of public administration, local authorities and blockage of vital industrial facilities and infrastructure;

8) blockade of Ukraine's efforts to counteract the monopolization of strategic sectors of the national economy with foreign capital, to eliminate dependence on monopoly supplies of critical raw materials, especially energy resources;

9) information and psychological warfare, abjection of Ukrainian language and culture, public abuse of the State Flag of Ukraine, the State Emblem of

\footnotetext{
${ }^{18}$ Проєкт Закону про захист української державності від проявів колабораціонізму (реєстр. № 7425 від 20.12.2017). URL: http://w1.c1.rada.gov.ua/pls/zweb2/webproc4_1?pf3511=63192 (Last accessed: 29.05.2020).
} 
Ukraine or the National Anthem of Ukraine, falsification of Ukrainian history, formation of "alternative reality" with the global narrative distorted by the media ${ }^{19}$.

Having analyzed this bill, O. Illarionov notes that this definition takes into account only the narrow concept of collaborationism and cuts off employees of state "agencies", enterprises, "scientific" institutions, "lawyers", media workers, etc. (except, of course, heads of "governmental bodies", "law enforcement agencies", war criminals, etc.), established on the basis of illegally seized property of all forms of ownership, which is not acceptable as collaboration is a conscious choice of a citizen, one's purposeful activity (public, professional, etc.), both active and passive $\mathrm{e}^{20}$. It is difficult to disagree with this point of view, as, while justifying the need to adopt this bill, authors noted: "Currently, persons involved in collaboration continue to hold or apply for high positions in the state, which is unacceptable. In addition, during the settlement of the conflict, many of these persons will be included in the amnesty, and they will fall under the legislative provisions regulating prevention of persecution and punishment of persons involved in activities carried out in the temporarily occupied territories. There is no doubt that collaborationism must be condemned, and certain rights of collaborators are limited in order to protect the national interests of Ukraine, ensure peace, security and democratic development of the state. In addition, such decision made by Verkhovna Rada of Ukraine will contribute to social harmony, resolution of this issue with full compliance to legal framework and avoidance of vigilantism. The state has no right to delink itself from the solution of this social problem" ${ }^{21}$.

It seems that introduction of the "collaborationism" concept was seen by authors of the bill as a simple way to create a register of collaborators, especially if we recall the proposal to form a Commission with the task to consider the facts of collaborationism (a subsidiary body established by the President of Ukraine to ensure national security and defense). However, it is not entirely clear from the content of the draft whether such persons should be held liable and to what extent, as the principle of individual responsibility was indicated.

The third bill No. 7426 "On amendments to the Criminal Code of Ukraine (concerning collaboration and enhancing the liability for treason)" (registered on 20.12.2017) was initiated by Verkhovna Rada MPs S. Vysotskyi, A. Levus,

\footnotetext{
${ }^{19}$ Проєкт Закону про захист української державності від проявів колабораціонізму (реєстр. № 7425 від 20.12.2017). URL: http://w1.c1.rada.gov.ua/pls/zweb2/webproc4_1?pf3511=63192 (Last accessed: 29.05.2020).

${ }^{20}$ Ілларіонов О. Захист від колабораціонізму: спроба друга. URL: https://blog.liga.net/user/aillarionov/ article/29863 (Last accessed: 29.05.2020).

${ }^{21}$ Проєкт Закону про захист української державності від проявів колабораціонізму (реєстр. № 7425 від 20.12.2017). URL: http://w1.c1.rada.gov.ua/pls/zweb2/webproc4_1?pf3511=63192 (Last accessed: 29.05.2020).
} 
I. Lapin, M. Bondar, M. Velychkovych, D. Tymchuk, T. Kremin, I. Brychenko and O. Medunytsia and presented amendments to Article 111 of the Criminal Code of Ukraine formulated as:

"Article 111. Treason

1. Treason, i.e. an act intentionally committed by a citizen of Ukraine to compromise sovereignty, territorial integrity and inviolability, defense capacity, state, economic or information security of Ukraine: adhering to the enemy in a state of war or armed conflict, espionage, provision of assistance in carrying out subversive activities against Ukraine to foreign states, organizations or its representatives, conscious and voluntary cooperation with the aggressor in its favor, holding positions, including elective ones, in the occupant's authorities, -

shall be punished with imprisonment for a term from twelve to fifteen years with deprivation of the right to hold positions covered by the Law of Ukraine "On Civil Service", positions of the Head of Administration of the President of Ukraine and his/her deputies, Permanent Representative of the President of Ukraine in the Autonomous Republic of Crimea and his/her deputies, Chairperson and members of the National Council of Ukraine on Television and Radio Broadcasting, Chairperson and members of the Antimonopoly Committee of Ukraine, Chairperson and members of the National Agency for Corruption Prevention, Chairperson and members of the Accounting Chamber, Chairperson and members of the Central Election Commission, Secretary of the National Security and Defense Council and his/her deputies, Chairperson of the State Committee for Television and Radio Broadcasting of Ukraine and his/her deputies, Chairperson of the State Property Fund of Ukraine and his/her deputies, the Verkhovna Rada Commissioner for Human Rights, Chairperson of the Council of Ministers of the Autonomous Republic of Crimea and his/her deputies, judges, prosecutors to become a member of the Cabinet of Ministers of Ukraine, First Deputy and Deputy Minister, official of the National Bank of Ukraine, deputy of the Verkhovna Rada of the Autonomous Republic of Crimea, Minister of the Autonomous Republic of Crimea, deputy of local councils, local self-governance body official, law enforcement officer (ranks and commanding officers) and employee other bodies with special ranks assigned, a serviceman of the Armed Forces of Ukraine and other military formations established in accordance with the law, for a period of ten years (with or without confiscation of property).

2. A citizen of Ukraine shall be exempt from criminal liability if he/she has not taken any action to perform the criminal task of a foreign state, foreign organization or its representatives and has voluntarily declared one's relation to these to the public authorities with the task given. 
Note. 1. The aggressor state in this article should be understood as a state recognized as an aggressor by the Verkhovna Rada of Ukraine.

2. Occupational bodies in this article should be understood as any bodies, selfproclaimed or established by the aggressor state, which performed or are performing functions inherent to state authorities or local self-government bodies within the territory of Ukraine recognized by the Verkhovna Rada of Ukraine as occupied ones. Thus, the only mention of collaborationism in this bill is an indication of the occupying authorities and the aggressor state" ${ }^{, 22}$.

We believe that despite the desire of the bill drafters "to protect the national interests of Ukraine in the face of Russian aggression, enhancing liability for treason, criminalization of collaboration, which equates to treason", if adopted with such wording, it would complicate Article 111 of the Criminal Code of Ukraine with the list of positions, which would be covered by this regulation and consequently, significantly limit its practical application.

Finally, the draft No. 2549 "On amendments to selected legislative acts of Ukraine (on the establishment of criminal liability for collaboration)" of December 6, 2019, submitted by Verkhovna Rada MP O. Savchuk. Substantiating the need to amend the Criminal Code of Ukraine, she pointed out that "collaborationism is a criminal offense not defined by law as a special form of treason expressed as military, political, economic, administrative, cultural, informational, media cooperation of a citizen of Ukraine with the aggressor state or its representatives, illegal armed groups established or maintained by them"23. The draft law provides for the amendment of Article 111-1 of the Criminal Code of Ukraine as follows:

"Article 111-1. Collaborationism

1. Collaborationism, i.e. a special form of treason expressed as military, political, economic, administrative, cultural, informational, media cooperation of a citizen of Ukraine with the aggressor state or its representatives, illegal armed groups established or maintained by them, compromising state sovereignty, territorial integrity and inviolability, defense capability, state, economic or information security of Ukraine, -

shall be punished by imprisonment for a term from three to five years with or without confiscation of property.

2. The same acts, if committed by a person who is a representative of the authorities, either repeatedly or in prior conspiracy by a group of persons, or combined with incitement to ethnic or religious disputes, -

\footnotetext{
22 Проєкт Закону про внесення змін до Кримінального кодексу України (щодо колабораціонізму та посилення відповідальності за державну зраду) (реєстр. № 7426 від 20.12.2017). URL: http://w1.c1.rada.gov.ua/pls/zweb2/ webproc4_1?pf3511=63193 (Last accessed: 29.05.2020).

23 Проєкт Закону про внесення змін до деяких законодавчих актів України (щодо встановлення кримінальної відповідальності за колабораціонізм) (реєстр. № 2549 від 06.12.2019). URL: http://w1.c1.rada.gov.ua/pls/zweb2/ webproc4_1?pf3511=67568 (Last accessed: 29.05.2020).
} 
shall be punished by imprisonment for a term from five to ten years with or without confiscation of property.

3. Actions covered by parts one or two of this article, which resulting in human death or other serious consequences, -

shall be punished by imprisonment for a term from ten to fifteen years or life imprisonment with or without confiscation of property.

4. Public appeals to collaboration, as well as the production of materials with appeals to collaboration for the purpose of its distribution, -

shall be punished by correctional labor for a term up to two years or by arrest for a term up to six months, or by imprisonment for a term up to three years" 24 .

Noting that collaborationism is a form of treason, we must remember that treason is an act intentionally committed by a citizen of Ukraine, which compromises sovereignty, territorial integrity and inviolability, defense capacity, state, economic or information security of Ukraine: adhering to the enemy in wartime or during an armed conflict, espionage, providing assistance to a foreign state, foreign organization or their representatives in performance of subversive activities against Ukraine. Therefore, the very fact of consent provision for certain actions (for example, to join the police force) is only a preparation for the commission of a crime and leaves the possibility to voluntarily renounce the crime. The commission of socially dangerous acts by a citizen of Ukraine in the interests of an enemy state under other articles of the criminal law (infringement on life of a statesman or public figure, sabotage, etc.) should be classified as a set of crimes under Article 111 and, accordingly, Articles 112 or 113 of the Criminal Code of Ukraine.

In our opinion, such bill actually duplicates the provisions of Article 111 "Treason" of the Criminal Code of Ukraine and creates a significant discrepancy resulting in contradicting norms applied by law enforcement.

\section{CONCLUSIONS}

Our analysis of the collaborationism concept and criminalizing bills allows us to conclude that most of them use the terms "aggressor", "occupying power" or "enemy". At the same time, such terms are not defined in these drafts, and therefore it is difficult to determine the concept, which will mostly result in qualification of such actions under Article 111 of the Criminal Code of Ukraine.

Six years of events in the East of Ukraine objectively determine the concept of "collaborationism" in domestic legislation. However, we should agree with O. Illarionov that "activities aimed to expose the actions of collaborators,

\footnotetext{
24 Проєкт Закону про внесення змін до деяких законодавчих актів України (щодо встановлення кримінальної відповідальності за колабораціонізм) (реєстр. № 2549 від 06.12.2019). URL: http://w1.c1.rada.gov.ua/pls/ zweb2/webproc4_1?pf3511=67568 (Last accessed: 29.05.2020).
} 
systematization and recording of them in current digital environment should be conducted by civil society, which should become a driver and incentive for public decision-making... Ukraine should also consider establishing an international tribunal to convict collaborators by the type (area) of activity. International tribunals and its decisions are extremely useful for the development of an international convention framework within the UN. The international significance of such process will reduce the possibilities for rights abuse and will help to avoid accusations of bias, inhumanity, secrecy and other manipulative manifestations by various media as propaganda tools used by the aggressor country and its satellites" 25 .

\section{SUMMARY}

Suggestions to introduce the legal institute of collaborationism have been frequently pronounced due to the events at the East of Ukraine, and this made research hereinafter mentioned relevant. The purpose of the article is to define essence of collaborationism and to analyze different bills, which stipulate its criminalization. Methods. Dialectic, logical, regulatory and legal systemic analysis methods have been used during this research. Findings of the research. It has been mentioned that modern researchers differentiate collaborationism, which involves a political agreement with the occupier (cooperation with the occupying power in civilian areas), and collaborationism as a fighting in favor of the occupying forces. Besides this, the following types of collaborationism could be distinguished with regard to certain spheres of activity - domestic, administrative, economic, military, political and military-political. The latter two forms were the most common (and punishable) in Europe during World War II, resulting in establishment of nominally independent governments or administrative institutions, pro-Nazi movements and parties along with formation of foreign legions. An analysis of collaborationism essence (as well as bills which stipulate its criminalization) allows to conclude that most of the latter use the terms "aggressor", "occupying power" or "enemy". Such terms are not defined in these bills, and therefore it is difficult to determine the collaborationism essence. The point of view has been outlined that criminal responsibility for all types of collaborationism is not necessary as far as there are plenty of other relevant articles of the Criminal Code of Ukraine in chapters on crimes against grounds of national safety and public safety. It has been suggested to introduce the definition and characteristics of collaborationists, but regulate the matter in question on the international level.

\footnotetext{
25 Ілларіонов О. Захист від колабораціонізму: спроба друга. URL: https://blog.liga.net/user/aillarionov/ article/29863 (Last accessed: 29.05.2020).
} 


\section{REFERENCES}

1. Пивоварська К. Колабораціонізм у Другій світовій війні. 1941 рік на Полтавщині: людський вимір трагедї та героїзму : збірник статей за матеріалами міжнародної наукової конференції (28 вересня 2011 року). Полтава : ПОІППО, 2011. С. 101-105.

2. Аваков А. Коллаборационизм и амнистия. Необходимость общественного диалога. Украӥнська правда. 2018. 6 червня. URL: https://www.pravda.com.ua/articles/2018/06/6/7182517 (Last accessed: 29.05.2020).

3. Литвиненко О.М. Досвід національного примирення: різні шляхи до однісї мети. Стратегічні пріоритети. 2019. № 1. С. 44-57.

4. Колабораціонізм у роки Другої світової війни. URL: http:// www.adm-pl.gov.ua/story/kolaboracionizm-u-roki-drugoyi-svitovoyi-viyni.

5. Коровин В.В. Правовая ответственность коллаборационистов в период Великой Отечественной войны. URL: https://elibrary.ru/download/ elibrary_24371447_64111459.pdf.

6. Чачава В. Кавказький вектор колабораціоністської політики Третього рейху (1991-1945). Історико-політичні проблеми сучасного світу : зб. наук. пр. 2015. Т. 29-30. С. 343-348.

7. Шайкан В. Колабораціонізм в Україні у роки Другої світової війни. URL: http://www.kby.kiev.ua/ komitet/conference/Shajkan2.pdf.

8. Духневич В.М. Психологічні наслідки воєнного конфлікту на Сході: теоретичний аналіз явищ політико-правової сфери. Наукові студіï iз соціальної та політичної психологї̈. 2018. Вип. 41. С. 31-45.

9. Юридична енциклопедія: в 6 т. / редкол.: Ю.С. Шемшученко (голова редкол.) та ін. Київ : «Укр. енцикл.», 2001. Т. 3: К-М. 2001. 792 с.

10. Дерейко I.I. Колабораціонізм. Енциклопедія історії України: в 10 т./ редкол.: В.А. Смолій (голова) та ін. Інститут історії України НАН. Київ : Наукова думка, 2007. Т. 4. С. 440-441.

11. Рубащенко М.А. Кримінальна відповідальність за колабораціонізм за чинним КК України. Соціальна функція кримінального права: проблеми наукового забезпечення, законотворення та правозастосування : матеріали міжнар. наук.-практ. конф. (м. Харків, 12-13 жовт. 2016 р.). Харків, 2016. С. 328-331.

12. Письменський Є.О. Кримінально-правова політика України із забезпечення охорони національної безпеки в умовах гібридної війни. II Львівський форум кримінальної юстищї «Правова реформа у сфері кримінальної юстиції: ключові параметри та прогноз подальшого розвитку» : збірка тез міжнар. наук.-практ. конф. (Львів, 23-24 верес. 2016 р.). Київ : BAITE, 2016. С. 159-165. 
13. Колабораціонізм і амністія: необхідність суспільного діалогу. URL: https://espreso.tv/article/2018/06/06/kolaboracionizm_i_amnistiya_neobk hidnist_suspilnogo_dialogu (Last accessed: 29.05.2020).

14. Проєкт Закону про заборону колабораціонізму (реєстр. № 6170 від 09.03.2017). URL: http://w1.c1.rada.gov.ua/pls/zweb2/webproc4_1?pf3511= 61312 (Last accessed: 29.05.2020).

15. Законопроєкти проти «колаборантів»: відповідальність - чи кара «наосліп»? URL: https://jfp.org.ua/blog/blog/blog articles/23 (Last accessed: 29.05.2020).

16. Проєкт Закону про внесення змін до Кримінального кодексу України (щодо колабораціонізму та посилення відповідальності за державну зраду) (реєстр. № 7426 від 20.12.2017). URL: http://w1.c1.rada.gov.ua/pls/zweb2/ webproc4_1? pf3511=63193. (Last accessed: 29.05.2020).

17. Проєкт Закону про захист української державності від проявів колабораціонізму (реєстр. № 7425 від 20.12.2017). URL: http:// w1.c1.rada.gov.ua/pls/zweb2/webproc4_1?pf3511=63192 (Last accessed: 29.05.2020).

18. Ілларіонов О. Захист від колабораціонізму: спроба друга. URL: https://blog.liga.net/user/aillarionov/article/29863 (Last accessed: 29.05.2020)

19. Проєкт Закону про внесення змін до деяких законодавчих актів України (щодо встановлення кримінальної відповідальності за колабораціонізм) (реєстр. № 2549 від 06.12.2019). URL: http:// w1.c1.rada.gov.ua/pls/zweb2/webproc4_1?pf3511=67568. (Last accessed: 29.05.2020).

\section{Information about authors: Politova A. S.,}

$\mathrm{Ph}$. D. of Law Sciences, Associate Professor, Associate Professor at the Department of Legal Disciplines Donetsk Law Institute of Ministry of Internal Affairs of Ukraine 89, Lunina avenue, Mariupol, Donetsk region, 87500, Ukraine

Akimov M. O.,

$\mathrm{Ph}$. D. of Law Sciences, Associate Professor, Associate Professor at the Department of Criminal Law

National Academy of Internal Affairs 1, Solomyanska square, Kyiv, 02000, Ukraine 